\title{
JEJAK BUDAYA PENAJAM PASER UTARA DALAM CERITA ASAL USULNYA
}

\section{CULTURAL TRACES ON PENAJAM PASER UTARA'S ORIGIN}

\author{
Aquari Mustikawati \\ Kantor Bahasa Kalimantan Timur \\ Jalan Batu Cermin 25, Samarinda \\ Pos-el: sunburn_4s@yahoo.co.id
}

*) Naskah masuk: 17 Maret 2019. Penyunting: Diyan Kurniawati, M.Hum. Suntingan I: 26 April 2019. Suntingan II: 16 Mei 2019.

\begin{abstract}
Abstrak
Penelitian ini menggambarkan jejak budaya masyarakat Penajam Paser Utara melalui cerita sal-usulnya. Jejak budaya tersebut meliputi sistem nilai, norma sosial, pola pikir, dan etos kerja masyarakat Penajam Paser Utara pada masa dahulu. Dalam penelitian ini digunakan metode pustaka untuk pengumpulan data dan kualitatif yang bersifat deskriptif, yaitu dengan cara mendeskripsikan cara-cara kejadian yang pernah ada dalam cerita. Cerita tersebut berupa sejarah, legenda atau kejadian penting, termasuk di dalamnya tentang tokoh penting yang pernah ada. Dengan menggunakan teori budaya, tulisan ini menganalisis budaya masyarakat Penajam Paser Utara masa lampau melalui cerita asal-usulnya. Hasil penelitian menunjukkan bahwa masyarakat Penajam Paser Utara masa lampau merekam kearifan lokal masing-masing daerahnya dalam cerita asal-usul. Dari hasil penelitian dapat disimpulkan bahwa cerita asal-usul Penajam Paser Utara dapat digunakan sebagai panduan memahami sejarah masyarakat untuk pengembangan potensi daerah tersebut.
\end{abstract}

Kata kunci: budaya, asal-usul, sejarah, kearifan lokal

\begin{abstract}
This research describes cultural traces of Penajam Paser Utara's people through its origin consisting of value system, social norms, mindset, and work ethic of the people in the past. It discusses about cultural traces recorded in the origin of Penajam Paser Utara's people. It uses library method to search data. It applies qualitative method to describe events in the past, like history, legends, or important events, including important figures that had ever existed. Cultural theory is used to analyze the culture of the people through their origin. The results of this study indicate that Penajam Paser Utara's in the past recorded their local wisdom of each region on their origin. It can be concluded that Penajam Paser Utara's origin can be used as knowledge to understand the history of the people so as to develop the potential of the region.
\end{abstract}

Keywords: culture, origin, history, local wisdom

\section{PENDAHULUAN}

Cerita tradisional adalah warisan kekayaan budaya yang sampai dengan saat ini menjadi bahan penelitian menarik bagi ahli folklor, sejarah, dan sastra karena kelengkapan isi yang dikandunganya. Pudentia 
memberikan gambaran bahwa produk kultural itu sangat cocok untuk digunakan dalam memahami pandangan hidup suatu masyarakat secara komprehensif (2003:1). Hal itu dikarenakan cerita tradisional mengandung beberapa komponen kultural yang menyangkut sendi-sendi kehidupan masyarakat pada masanya, yaitu berupa sisitem nilai, yaitu religi, kaidah dan keberlangsungan kehidupan sosial, pola pikir, dan etos kerja.

Namun, dalam pandangan masyarakat modern, kepentingan akan pengetahuan pemikiran nenek moyang dianggap tidak diperlukan. Padahal sebagai bagian dari produk kultural yang selalu bersifat dinamis, cerita tradisional merangkum dan mendokumnetasikan segala pola pikir dan perilaku manusia dari masa ke masa. Perubahan pola pikir manusia dari masa ke masa tersebut yang sering disebut dengan rasionalisasi. Rasionalisasi adalah upaya manusia untuk mencegah ketidakstabilan yang terjadi dalam kehidupannya (Indrastuti, 2008: 189). Sebagai manusia yang berbudaya, manusia dari masa ke masa berusaha memperbaiki dan meningkatkan kehidupannya menuju kualitas hidup yang lebih baik. Proses peningkatan kehidupan tersebut memanfaatkan pemikiran manusia untuk mengembangkan kemampuannya dan kecenderungannya. Kesemuanya itu tidak hanya untuk kelangsungan hidupnya, tetapi juga untuk perwujudan eksistensialnya (Geertz, 1992). Selain untuk mewujudkan kualitas hidup yang lebih baik, perkembangan peradaban juga menunjukkan pentingnya eksistensi masyarakat untuk membedakan mereka dengan yang lain. Dengan begitu mereka berlomba-lomba untuk menunjukkan yang terbaik dari hasil pemikiran mereka berupa warisan budaya benda dan tidak benda. Warisan budaya tersebut menunjukkan usaha manusia untuk mencapai peradaban yang semakin tinggi.
Salah satu warisan budaya tidak benda adalah buah pikiran yang dituangkan dalam tradisis lisan, salah satunya adalah cerita tradisional. Kuntowijoyo menjelaskan bahwa norma dan cita-cita egaliter suatu masyarakat terwujud dalam cerita tradisional yang menunjang ideologi mereka (2006:7). Ideologi sebagai produk budaya termasuk dalam perwujudan budaya masyarakat yang sifatnya tidak statis. Perubahan tersebut dipengaruhi oleh perubahan sosial dalam masyarakat. Perubahan-perubahan budaya dapat terlihat melalui cerita tradisional yang merekam dan mendokumentasikan pola pikir masyarakat pada masanya.

Cerita tradisional Kabupaten Penajam Paser Utara memiliki keunikan tersendiri. Hal itu disebabkan wilayah tersebut merupakan kabupaten baru yang masih memiliki keterikatan budaya yang kuat dengan kabupaten induknya, yaitu Kabupaten Paser. Sebagian besar masyarakat di kabupaten tersebut merupakan suku Paser. Namun, kabupaten yang sebagian wilayahnya terletak di pinggir laut ini juga merupakan daerah tujuan masyarakat pendatang dari daerah lain, yaitu salah satunya dari Sulawesi. Perpaduan budaya pendatang dan masyarakat asli di daerah tersebut merupakan suatu bentuk asimilasi budaya di wilayah Penajam Paser Utara. Selain itu, wilayah Penajam Paser Utara secara administratif memiliki sejarah yang berhubungan dengan Balikpapan, Kutai Kartanegara, dan Paser. Perubahanperubahan tersebut terekam dan terdokumentasi dalam cerita tradisionalnya, terutama cerita asal-usul. Berdasarkan hal tersebut, penelitian ini memfokuskan permasalahan pada jejak budaya masa lampau apa saja yang terekam dalam cerita asal-usul masyarakat Penajam Paser Utara?

\section{TEORI}

Cerita tradisional adalah bagain dari folklor yang disebarkan secara turun-me- 
nurun. Dundes (dalam Bronner, 2007:20) memaparkan bahwa bahwa folklor tidak hanya dikaji dari segi teks secara harafiah, tetapi dihubungkan dengan konteks yang menunjukkan kondisi sosial dan perilaku masyarakat. Oleh karena itu, folklor memiliki fungsi bagi masyarakat. Selain itu, Amir (2013:2021) menambahkan bahwa folklor mempunyai dua fungsi, yaitu (1) memperkuat rasa persatuan kelompok dan (2) menyimpan kearifan lokal (local wisdom), kecendekiaan tradisional (traditional scholarly), pesan-pesan moral, dan nilai sosial dan budaya.

Fox (1986:44) menerangkan bahwa setiap teks (dalam hal ini cerita rakyat) terdiri atas (1) seperangkat hubungan internal yang mengatur koherensinya; (2) seperangkat hubungan asosiatif yang mengaitkannya dengan teks-teks lain dalam korpus budaya; dan (3) seperangkat acuan yang menunjuk pada satuan-satuan kondisi dan kejadian yang ada di luar teks itu sendiri. Koherensi internal, pola asosiatif, dan tatanan acuan secara bersama-sama membentuk struktur komunikatif dan interaksi antara hubunganhubungan subteks menggunakan asumsi budaya dan kriteria komposisi yang tepat.

\section{METODE}

Metode yang digunakan meliputi metode pencarian data dan analisis. Metode pencarian data dilakukan dengan metode pustaka, yaitu mencari bahan dari cerita rakyat Penajam Paser Utara dalam buku Serpihan Cerita Rakyat Kalimantan Timuryang diterbitkan Kantor Bahasa Kalimantan Timur (2018). Selanjutnya, metode pustaka dilakukan dengan cara membaca cermat cerita Penajam Paser Utara yang berhubungan dengan penelitian ini. Proses selanjutnya melakukan klasifikasi data yang dilakukan dengan cara mencatat bagian paragraf dan kalimat yang mengungkapkan suatu peristiwa asal usul. Setelah proses pencarian data selesai dilakukan, proses analisis dimulai.
Metode yang digunakan dalam proses analisis adalah kualitatif. Proses ini memuat kegiatan mengungkap kejadian yang pernah terjadi dalam cerita yang berupa sejarah, legenda atau kejadian penting, termasuk di dalamnya adalah tentang tokoh penting yang pernah ada. Proses selanjutnya menganalisis bagian cerita menggunakan teori budaya.

Penelitian ini menggunakan pendekatan antropologi sastra, yaitu suatu pendekatan yang dilakukan terhadap penelitian orientalis yang dilakukan bangsa-bangsa timur untuk mengetahui tingkat kehidupan dan peradaban bangsa tersebut (Ratna, 2011:28). Lebih lanjut Ratna menjelaskan bahwa antropologi sastra adalah analisis dan pemahaman terhadap karya sastra dalam kaitannya dengan kebudayaan. Kebudayaan yang berhubungan dengan cerita asal-usul Kabupten Penajam Paser Utara dapat dijelaskan dalam penelitian ini.

\section{HASIL DAN PEMBAHASAN}

Cerita tradisional atau cerita rakyat berkisah tentang peristiwa sehari-hari yang dialami oleh masyarakat. Cerita rakyat menjadi menarik karena dibangun dari beberapa unsur (Indiarti, 2017:27). Keseluruhan unsur tersebut merupakan bagian-bagian yang tidak dapat dipisah-pisahkan yang merupakan perwujudan kearifan lokal masyarakat tertentu yang juga menyangkut kecendekiaan tradisional, pesan-pesan moral, dan nilai sosial dan budaya (2013:1 - 21). Hal itu menerangkan bahwa kelengkapan cerita tradisional merupakan suatu kekayan yang sangat penting untuk dikaji sebagai upaya mewujudkan pondasi bangsa yang kuat.

Cerita yang termasuk dalam cerita asalusul dalam cerita rakyat Kabupaten Penajam Paser Utara adalah cerita tradisional yang memiliki keterkaiatan dengan awal mula suatu daerah. Awal mula tersebut dapat berupa suatu kejadian atau peristiwa penting 
yang pernah terjadi di daerah tersebut, fenomena alam, legenda yang berkembang dalam masyarakat, dan tokoh yang dianggap penting di daerah tersebut. Baik kejadian penting, legenda yang berkembang dalam masyarakat, fenomena alam, maupun tokoh penting seringkali diabadikan dalam nama suatu daerah. Sukojo mengatakan bahwa nama-nama suatu daerah sudah ada sejak dahulu dan diturunkan secara turun-temurun baik dalam dokumenn yang tercatat maupun dalam bentuk folklor (2012:7). Lebih lanjut Sukojo menerangkan bahwa umumnya masyarakat tradisional memberikan nama suatu daerah berdasarkan sejarah tempat yang bersangkutan, legenda, dan fenomena alam yang spesifik.

\section{Cerita Asal-usul dan Penamaan}

Penamaan daerah berdasarkan awal mula suatu daerah dimaksudkan untuk mengingatkan masyarakat tentang kejadian yang membentuk suatu daerah. Hal itu sangatlah penting kareana kehidupan manusia tidak dapat terlepas dari sejarahnya. Melalui sejarah, manusia dapat belajar memahami karakteristik yang dimilikinya berdasarkan karakteristik nenek moyangnya. Selain itu, masyarakat dapat meningkatkan kehidupannya dengan cara belajar melalui cara-cara nenek moyang berkehidupan di masa lampau. Untuk itulah penamaan daerah berdasarkan kisah awal mula daerah tersebut sangatlah penting sebagai bahan kajian antropologi sastra yang mengkaji cerita dibalik penamaan daerah.

\section{Penamaan Berdasarkan Legenda}

Beberapa daerah di Kabupaten Penajam yang penamaannya berdasarkan legenda dapat ditemukan dalam cerita asal usul daearah Penajam versi masyarakat Paser. Dalam cerita tersebut legenda batu asah yang terdapat di daerah Penajam sebagai awal mula nama daerah Penajam. Batu asah yang digunakan masyarakat Paser Balik untuk menajamkan senjata mereka sebelum bertarung melawan bajak laut di selat Balikpapan.

Sebelum berangkat menuju Balikpapan, mereka terlebih dahulu menjamkan senjata di sebongkah batu yang terdapat di sebuah daerah. Penduduk Paser yang akan bepergian melewati Teluk Balikpapan kemudian terbiasa mengasah parang di sebongkah batu di daerah tersebut. Mengasah batu di daerah tersebut menjadi hal rutin dan suatu keharusan bagi mereka yang bepergian melewati Teluk Balikpapan (Rifai et al., 2018:29_ 30).

Nama daerah lainnya yang berasal dari legenda adalah Pemaluan. Legenda tentang seorang yang sangat pemalu. Putri Rintik Manik, seorang gadis cantik, anak seorang tuo kampong yang sangat pemalu. Oleh karena keberadaan putri pemalu yang ada di kampung tersebut, akhirnya kampung tersebut dinamakan kampung Pemaluan.

Legenda pengeboran minyak yang dilakukan oleh orang Belanda telah menjadikan suatu daerah dinamakan Gunung Hantu. Pengeboran minyak yang menurut legenda diganggu oleh makhluk gaib tidak dapat diteruskan. Menurut cerita, makhluk gaib tersebut meminta tumbal kepala orang Belanda yang memimpin proyek pengoboran agar pekerjaan pengeboran dapat dilaksnaakan. Namun, pengeboran tidak diteruskan karena orang Belanda tidak memenuhi permintaan makhluk gaib tersebut.

Legenda kesaktian punggawa Serangkak Tulang Tunggal, pemimpin Tanah Balik yang luar biasa telah melahirkan nama daerah Balikpapan. Pada waktu itu Sultan Kutai ingin menguasai Tanah Balik dan mengirimkan utusan untuk menemui punggawa Serangkak Tulang Tunggal agar menarik upeti di Tanah Balik untuk Kesultanan Kutai. Punggawa Serangkak Tulang 
Tunggal tidak langsung menolak permintaan Sultan Kutai. Ia menyanggupi mengirim papan dengan syarat bahwa apabila bisa bertahan empat puluh empat hari empat puluh empat malam di istana Kutai, dia beserta rakyat Paser Balik siap tunduk pada kerajaan Kutai. Namun, ternyata pada hari ke tujuh papan rewan hilang di istana Kutai secara misterius dan kembali ke rumah Kuta (rumah adat Paser) milik punggawa Serangkak Tulang Tunggal. Kejadian tersebut sebagai tanda bahwa Tanah Balik tidak mendapat restu dewa untuk tunduk pada Kesultanan Kutai. Kembalinya papan-papan tersebut menjadi nama daerah di Tanah Balik dengan nama Balikpapan.

Pada hari ke tujuh papan rewan hilang di istana Kutai secara misterius. Ternyata tujuh keping papan rewan itu kembali ke rumah Kuta ( rumah adat Paser) milik Punggawa Serangkak Tulang Tunggal. Melihat kejadian tersebut, Punggawa Serangkak Tulang Tunggal berkata," balik papan kuta endo". Kalimat tersebut berarti, tujuh papan rewan telah kembali ke rumah Paser (Rifai et al., 2018: 43).

Awal mula nama daerah Sepinggan berdasarkan kejadian pada masa dahulu ketika daerah tersebut masih disebut Tanah Balik. Anak buah kapal jung milik Aji Tatin yang membawa bantuan papan untuk pembangunan istana baru Kutai Kartanegara terdampar di daerah Tanah Balik setelah kapalnya karam di Selat Makasar. Di daerah tersebut mereka menjumpai para peladang yang sedang makan siang. Para peladang yang kasihan melihat kondisi anak buah kapal yang terdampar, menawari makan dari piring yang sama dengan para peladang. Dalam bahasa Paser sepinggan dapat diartikan sebagai satu piring. Berdasarkan kejadian tersebut daerah tersebut dinamakan Sepinggan.
Sebagian bekal makanan para peladang tersebut dibagikan kepada anak buah kapal yang sedang kelaparan. Mereka semua makan dari piring yang satu atau satu piring. Satu piring dalam bahasa Paser artinya sepinggan. Sejak saat itu daerah tempat peladang dari suku Paser Balik yang menolong anak buah kapal Aji Tatin yang tenggelam tersebut diberi nama Sepinggan (Rifai et al., 2018: 41).

Cerita asal mula daerah Jenebora berdasarkan kejadian masa lalu, yaitu ada pedagang dari Cina di daerah tersebut. Penamaan Jenebora diambil dari istilah dalam bahasa Paser Cinabora yang artinya Cina Putih. Istilah Cinabora kemudian berrubah menjadi Jenebora.

\section{Penamaan Berdasarkan Kejadian yang Pernah Terjadi}

Cerita asal-usul yang berdasarkan sejarah atau kejadian yang pernah terjadi di daerah tersebut juga terdapat dalam penamaan beberapa wilayah di kabupaten Penajam Paser Utara. Asal usul Penajam dalam bahasa Bugis termasuk dalam penamaan wilayah berdasarkan sejarah. Pada waktu itu ada sekelompok perampok di daerah Penajam yang dikalahkan oleh para perampok dari daerah Sangkulirang (Kutai Timur). Kekalahan tersebut menyebabkan mereka berniat berhenti atau pajan (berhenti dalam bahasa Bugis) menjadi perampok. Kata pajan kemudian berubah menjadi Penajam.

Nama daerah Nenang juga berdasarkan kejadian pada masa dahulu. Daerah Nenang pada masa itu digenangi air sampai ke pinggang sehingga masyarakat harus berenang atau jalan-jalan di air. Dalam bahasa Bugis, nenang artinya berenang atau berjalan-jalan di air. Oleh sebab itu, daerah tersebut kemudian dinamakan Nenang.

Asal usul nama daerah Nenang dalam versi masyarakat Paser juga berhubungan 
dengan kejadian pada masa lalu, yaitu caracara menangkap ikan. Cara menangkap ikan yang dilakukan masyarakat di daerah Nenang pada waktu itu dengan cara membendung air pasang menggunakan buluh-buluh bambu yang ditancapkan di sungai membentuk sebuah bendungan. Cara menangkap ikan seperti itu dalam bahasa Paser disebut betenangan. Dari kata betenangan, masyarakat kemudian menamakan daerah tersebut dengan nama Nenang.

Asal-usul nama Sungai Parit juga berhubungan dengan kejadian masa lalu, yaitu adanya sungai-sungai atau parit-parit untuk mengalirkan air ke laut. Pada masa dahulu daerah Sungai Parit dipenuhi air sehingga tidak dapat dihuni dan digunakan sebagai lahan pertanian. Agar masyarakat dapat tinggal dan bertani di daerah tersebut, mereka membuat sungai-sungai atau paritparit menuju laut. Parit-parit tersebut digunakan untuk mengaliri seluruh air di daerah tersebut ke laut. Berdasarkan kejadian itu, daerah tempat dibuatnya parit-parit dinamakan Sungai Parit.

Daerah Babalu juga memiliki sejarah yang berhubungan dengan asal-usul namanya. Pada masa pembukaan hutan di daerah tersebut banyak nyamuk yang menghinggapi para pembuka lahan di hutan. Banyaknya nyamuk yang ada menyerupai bulu. Masyarakat kemudian menyebut daerah tersebut dengan nama Babulu yang dalam dialek Melayu artinya berbulu.

Asal usul daerah Separe juga berdasarkan kejadian pada masa dahulu. Pada waktu itu para peladang di daerah tersebut memiliki kebiasaan meminjam benih padi tetangganya dengan cara membagi dari satu bonggol padi. Istilah separe dalam bahasa Paser artinya satu padi atau satu bonggol padi. Daerah tersebut kemudian dinamakan Separe berdasarkan kejadian berladang pada masa dahulu.
Daerah Gunung Seteleng diberi nama tersebut berdasarkan adanya meriam Jepang yang ada di daerah tersebut. Meriam tersebut digunakan Jepang untuk melawan tentara Sekutu. Meriam dalam bahasa Jepang adalah setelen. Orang-orang di daerah tersebut kemudian menamakan daerah tersebut dengan nama Gunung Seteleng.

\section{Penamaan Berdasarkan Fenomena Alam}

Cerita asal-usul suatu daerah tentang suatu kejadian fenomena alam diabadikan dalam nama daerahnya. Di kabupaten Penajam Paser Utara ditemukan beberapa daerah yang diberi nama berdasarkan keadaan alamnya.

Daerah Nipah-Nipah diberi nama tersebut karena pada masa dahulu daerah tersebut banyak pohon nipahnya. Daerah Nipah-Nipah terletak di sepanjang pantai atau daerah aliran pasang surut. Sementara itu, daerah Petung dinamakan tersebut karena pada masa dahulu di daerah tersebut terdapat banyak tanaman bambu yang dalam bahasa Paser disebut dengan petung. Daerah Gersik diberi nama berdasarkan keadaan alamnya yang banyak mengandung pasir. Dalam bahasa Paser, pasir disebut dengan kersik. Oleh orang-orang Bugis yang tinggal di daerah tersebut pelafalan kersik berubah menjadi gersik, sehingga daerah tersebut dinamakan Gersik. Daerah Semayang diberi nama berdasarkan keadaan alamnya yang banyak tumbuh pohon pinang di daerah tersebut. Pohon pinang tersebut oleh orang Paser Balik diambil mayangnya atau bunganya untuk upacara pernikahan. Oleh karena banyaknya masyarakat yang mencari bunga mayang di daerah tersebut dalam bahasa Paser disebut dengan semanyang yang artinya mencari mayang. Sementara itu, daerah Petung diberi nama Petung karena pada masa lampau di daerah tersebut banyak bambu petung yang tumbuh di sekitar sungai Tunan. 
Oleh karena banyaknya bambu di sekitar anak sungai Tunan tersebut, masyarakat kemudian menamai sungai tersebut dengan nama Sungai Petung. Sementara itu, daerah yang berada di sekitar Sungai Petung dinamai pula dengan nama Petung. Kini, Petung merupakan salah satu nama kelurahan di Kecamatan Penajam (Rifai et al., 2018: 35).

\section{Penamaan Berdasarkan Orang yang Di- hormati}

Cerita asal usul yang mengabadikan nama tokoh berpengaruh dalam suatu wilayah juga ditemukan dalam cerita tradisional di Kabupaten Penajam Paser Utara. Selain tiga faktor yang dianggap sebagai sebab penamaan suatu daerah oleh masyarakat tradisional, ada satu faktor yang juga dijelaskan oleh Sukojo dalam bukunya di halaman berikutnya bahwa nama orang yang dianggap berjasa terhadap terbentuknya suatau daerah juga dapat diabadikan sebagai nama daerah. Dalam asal usul daerah di kabupaten Penajam Paser Utara ditemukan dua nama wilayah yang menggunakan nama tokoh berpengaruh yang dianggap berjasa terhadap daerah tersebut, yaitu pantai Lango dan sungai Aji Raden.

Nama daerah Pantai Lango diambil dari nama tokoh yang memelopori pembukaan lahan di daerah tersebut, yaitu Kakah Lango (Dato Lango). Sementara itu, nama sungai Aji Raden juga berasal dari tokoh pembuka daerah di wilayah Tanah Balik. Untuk mengenang jasa Aji Raden, sebuah sungai di daerah tersebut diberi nama sungai $\mathrm{Aji}$ Raden.

\section{Jejak Budaya}

Penamaan suatu daerah berdasarkan peristiwa yang pernah terjadi pada daerah tersebut adalah salah satu bentuk pelestarian akan suatu keraifan lokal. Berdasarkan nama suatu daerah, masyarakat dapat menelusuri jejak budaya daerah tersebut. Hal tersebut seperti yag dikatakan Amir (2013: 20 - 21) bahwa salah satu fungsi folklor adalah menyimpan kearifan lokal (local wisdom), kecendekiaan tradisional (traditional scholarly), pesan-pesan moral, dan nilai sosial dan budaya.

Budaya masa lampau yang dapat ditelusuri melalui cerita asal-usul Kabupaten Penajam Paser Utara yang meliputi keseluruhan fungsi folklor dan koherensi teks yang memiliki arti budaya. Beberapa hal budaya yang dapat diungkap dalam cerita asal-usul Kabupaten Penajam Paser Utara adalah sebagai berikut: kearifan lokal berupa gotong royong, kelestarian lingkungan, adaptasi manusia, dan politik.

Adaptasi manusia dapat dilihat dalam cerita asal-usul daerah Nenang dan Sungai Parit. Pada zaman dahulu, ketika wilayah Nenang dan Sungai Parit masih dipenuhi air sampai sepinggang manusia. Masyarakat beradaptasi dengan cara-cara menangkap ikan yang mereka sebut betenangan, yaitu dengan cara membendung air pasang menggunakan bulu-buluh bambu. Oleh karena wilayahnya yang dipenuhi air, masyarakat di daerah tersebut harus berjalan di air yang menggenang. Cerita asal-usul daerah Sungai Parit menerangkan kearifan masyarakat berupa adaptasi di daerah yang tergenang air dengan cara membuat parit-parit sampai ke laut untuk mengalirkan air di daerah tersebut ke laut. Cerita ini selain menerangkan kearifan lokal masyarakat, juga menunjukkan kecendikiaan lokal masyarakat yang memiliki pengetahuan membuat parit sampai ke laut untuk mengeringkan wilayah tersebut dari air yang menggenang.

Berdasarkan cerita asal-usul Nenang dan Sungai Parit dapat dipahami bahwa kedua daerah tersebut awalnya adalah daerah rawa. Dengan mengetahui riwayat daerah tersebut dapat diambil tindakan selanjutnya 
bagi kehidupan manusia yang lebih baik di daerah tersebut. Tindakan tersebut dapat berupa pencegahan terjadinya banjir atau genangan air kembali mengingat dahulunya daerah tersebut berupa rawa. Selain itu, perlu dipahami bahwa struktur tanah rawa bukanlah tanah padat. Hal itu perlu dipertimbangkan dalam membuat pemukiman di daerah tersebut.

Cerita asal-usul Penajam Paser Utara yang berhubungan dengan fenomena atau kejadian alam merupakan suatu acuan tentang kondisi alam di daerah tersebut. Seperti yang diutarakan oleh Fox bahwa suatu teks cerita tradisional juga merupakan seperangkat acuan yang menunjuk pada satuansatuan kondisi dan kejadian yang ada di luar teks itu sendiri (1986:44). Hal itu berarti bahwa cerita tradisional merupakan gambaran keadaan daerah dan aktivitas masyarakatnya pada masa tertentu. Lebih lanjut, cerita asal-usul yang menerangkan fenomena alam memiliki suatu pesan tententu yang berhubungan dengan keunikan daerah masing-masing.

Daerah Babulu menerangkan hambatan masyarakat masa lampau dalam membuka lahan pertanian di daerah pedalaman, yaitu diserang nyamuk yang sangat banyak. Hal itu menunjukan bahwa pada masa lampau daerah tersebut merupakan hutan belantara yang sangat rapat. Kondisi tersebut merupakan suatu petunjuk bahwa daerah tersebut merupakan daerah subur yang banyak ditumbuhi oleh tanaman. Berdasarkan hal tersebut, tindakan yang diambil manusia pada saat ini adalah berusaha mengembalikan kesuburan di wilayah tersebut dan menggunakannya untuk kemaslahatan manusia. Petunjuk akan kondisi alam pada masa lampau ditunjukkan melalui asal-usul daerah Petung, Nipah-nipah, dan Semayang. Cerita asal-usul ketiga daerah tersebut memberi petunjuk tentang keadaan alamnya yang sangat kaya akan jenis tanaman tertentu.
Salah satu ciri bambu petung adalah yang memiliki lingkar batang yang besar. Oleh karena besar dan kuatnya bambu petung, jenis tanaman ini sering digunakan untuk pembangunan rumah tradisional. Saat ini tanaman ini sangat sulit dijumpai di Indonesia.

Nilai sosial budaya, yaitu gotong royong dapat dilihat dalam cerita asal-usul daerah Separe dan Sepinggan. Keduanya menerangkan bahwa masyarakat di daerah tersebut memiliki sifat sosial yang patut dicontoh, yaitu saling menolong dan berbagi. Kearifan lokal tersebut seharusnya dapat tetap terjaga sampai dengan saat ini.

Cerita asal-usul yang menggambarkan lingkungan adalah asal-usul Patai Lango dan Sungai Aji Raden. Asal-usul Pantai Lango memiliki pesan untuk merawat dan menjaga lingkungan seperti yang dilakukan oleh tokoh Kakah Lango yang merintis untuk menetap di daerah hutan bakau. Beliau memberikan contoh bahwa alam akan bersahabat apabila manusia merawat dan menjaganya dengan baik. Tokoh Aji Raden yang namanya diabadikan sebagai nama sungai adalah tokoh yang memelopori dalam pembukaan daerah di Balikpapan. Selain itu, beliau adalah tokoh penting di Kerjaan Paser yang menumpas bajak laut di Teluk Balikpapan.

Nilai sosial budaya lainnya yang juga penting adalah politik yang terdapat dalam cerita asal-usul Balikpapan, Sepinggan dan Pulau Tokon. ketiga cerita tersebut saling berkaitan, yaitu tentang bantuan pengiriman papan kayu untuk pembangunan istana Kutai Kartanegara. Seperti diketahui, Kabupaten Penajam Paser Utara adalah pecahan dari Kabupaten Paser yang sebagain penduduknya adalah masyarakat Paser. Kabupaten Paser adalah daerah kerajaan, yaitu Kesultanan Paser. Namun, pembagian administratif pada masa penjajahan Belanda, Balikpapan dan wilayah Tanah Balik menjadi bagian dari Kesultana Kutai (Cribb, 
1902). Sebagai bagian dari Kesultanan Kutai secara administrtif, Sultan Kutai berhak meminta sumber daya alam Tanah Balik untuk Kesultanan. Dalam cerita asal-usul Balikpapan diterangkan bahwa pemimpin Tanah Balik pada saat itu, yaitu Punggawa Serangkak Tulang Tunggal sangat keberatan dengan keinginan Sultan Kutai meminta upeti berupa beberapa papan kayu yang sangat terkenal mutunya dari Tanah Balik. Namun, sebagai seorang pemimpin, Punggawa Serangkak Tulang Tunggal tidak serta merta menolak keinginan Sultan Kutai. Ia menolak dengan cara yang sangat berwibawa, yaitu menggunakan suatu pertanda apabila papan yang dikirim dapat bertahan di Kesultanan Kutai selama empat puluh hari, maka secara otomatis ia akan mengakui kekusaan Kesultana Kutai. Namun, ternyata papan kayu tersebut kembali ke Tanah Balik sebelum empat puluh hari. Hal itu menandakan bahwa Tanah Balik di bawah Punggawa Serangkak Tulang Tunggal tidak mau tunduk pada Kesultana Kutai. Sementara itu, cerita asal-usul Sepinggan dan Pulau Tokon saling berkaitan, yaitu tentang Aji Tatin.Beliau adalah salah satu putri Kesultana Paser yang menikah dengan salah satu bangsawan Kutai.

Aji Geger memiliki beberapa anak dan salah satunya adalah seorang perempuan yang bernama Aji Tatin. Aji Tatin menikah dengan seorang bangsawan dari Kerjaan Kutai Kartanegara. Oleh ayahnya, Sultan Aji Muhammad Alamsyah, Aji Tatin diberi sebuah hadiah pernikahan, yaitu sebuah wilayah kekuasaan di perbatasan Kutai Kartanegara dan Paser yang bernama Tanah Balik (Rifai et al., 2018: 47).

Secara politis, pemberian wilayah Tanah Balik kepada Aji Tatin dan suamunya adalah suatu bentuk peredam perselisihan antara Kesultana Kutai dan Paser.
Ayah Aji Tatin, yaitu Sultan Aji Muhammad Alamsyah membaca bahwa pernikahan putrinya dengan bangsawan Kutai merupakan suatu kerjasama politik yang dapat digunakan untuk merekatkan hubungan Paser dengan Kutai. Sultan Aji Muhammad Alamsyah sengaja memberi kekuasaan kepada Aji Tatin dan suaminya di Tanah Balik yang merupakan perbatasan Kutai dan Paser agar kedua kerajaan tidak saling menyerang lewat perbatasan di Tanah Balik (Mustikawati, 2016: 181).

Cerita asal-usul Sepinggan dan Pulau Tokon mengenai karamnya kapal Aji Tatin yang mengangkut kayu untuk pembangunan istana Kutai yang baru. Kesultanan Kutai kembali meminta kayu dari Tanah Balik kali ini melalui hubungan kekerabatan, yaitu melalui suami Aji Tatin. Aji Tatin menyanggupinya dengan mengirim beberapa papan menggunakan kapal jung. Akan tetapi, kapal tersebut karam di Selat Makasar. Sebagaian awak kapal yang selamat ditolong oleh peladang dan mendapat makanan dalam satu pinggan, sedangkan tokon atau dayung kapal terdampar di salah satu pulau di Teluk Balikpapan. Kedua cerita asalusul tersebut mnnceritakan pengiriman papan kayu ke Kutai yang gagal untuk kedua kalinya.

\section{PENUTUP}

Sebagai warisan kekayaan budaya cerita asal-usul Kabupaten Penajam Paser Utara berisikan komponen budaya yang berhubungan dengan dasar-dasar kehidupan masyarakat, yaitu sistem nilai, norma sosial, pola pikir, dan etos kerja masyarakat pada masa dahulu. Selain merangkum dan mendokumentasikan kehidupan dan pola pikir masyarakat dari masa ke masa, cerita asal-usul Kabupaten Penajam Paser Utara 
mengungkapkan hubungan sejarah dengan Balikpapan, Kutai Kartanegara dan Paser.

Masyarakat di wilayah Kabupaten Penajam Paser Utara, memberikan nama suatu daerah berdasarkan kejadian penting di masa lalu, legenda, fenomena alam, dan tokoh yang berperan penting dalam pengembangan daerah tersebut. Penamaan tersebut bertujuan untuk mengingatkan masyarakat kini tentang asal mula daerahdaerah di Kabupaten Penajam Paser Utara. Jejak budaya yang terdapat dalam cerita asal-usul tersebut meliputi kearifan lokal berupa gotong royong, kelestarian lingkungan, adaptasi manusia, dan politik. Berdasarkan keraifan lokal tersebut masyarakat dapat mengetahui karakter dan keunikan daerah Penajam Paser Utara.

Setiap daerah memiliki keunikan, kelebihan, dan kekurangan. Dengan memahami itu semua, manusia dapat meningkatkan kualitas hidupnya dengan cara mengembangkan potensi yang dimiliki oleh daerah. Demikianjuga dengan pembangunan di daerah Penajam Paser Utara, pemerintah sebaiknya memahami dengan benar kareakteristik tersebut untuk menghindari konflik dan lebih memaksimalkan pembangunan di daerah tersebut.

\section{DAFTAR PUSTAKA}

Amir, A. 2013. Sastra Lisan Indonesia. Yogyakarta: C.V Andi Offset.

Bronner, S. J. 2007. The Meaning of Folklore: The Analytical Essays of Alan Dundes. Utah: Utah State University Press.

Cribb, R. 1902. Administrative divisions in Dutch Borneo. Retrieved from http:// www.indonesianhistory.info/map/ borneo1902.html

Fox, J. J. 1986. Bahasa, Sastra, dan Sejarah: Kumpulan Karangan Mengenai Masyatakat Pulau Roti. Jakarta: Djambatan.
Geertz, C. 1992. Tafsir Kebudayaan. Terjemahan Franscisco Budi Hardiman dari The Interpretation of Cultures. Yogyakarta: Kanisius.

Indiarti, W. 2017. Nilai-nilai Pembentukan Karakter dalam Cerita Rakyat Asal-Usul Watu Dodol. Jentera, Jurnal Kajian Sastra, 6(Folklor), 27. Retrieved from http:// ojs.badanbahasa.kemdikbud.go.id/ jurnal/index.php/jentera/article/ view/334

Indrastuti, N. S. K. 2008. Representasi Unsur Budaya dalam Cerita Rakyat Indonesia: Kajian Terhadap Status Sosial dan Kebudayaan Masyarakat. Malaysian Journal of Social Sciences and Humanities (MJ - SSH), 3(folktale), 189-199.

Kuntowijoyo. 2006. Budaya dan Masyarakat (Paripurna). Yogyakarta: Tiara Wacana. Mustikawati, A. 2016. Cerita Rakyat Masyarakat Penajam Paser Utara: Fakta Sejarah Kesultanan Kutai Kartanegara dan Kesultanan Paser. Totobuang, 4(folklor), 177-189. Retrieved from http:/ / totobuang.kemdikbud.go.id/ jurnal/index.php/totobuang

Pudentia. 2003. Antologi Prosa Rakyat Melayu Indonesia. Jakarta: Pusat Bahasa.

Ratna, N. K. 2011. Antropologi Sastra Peranan Unsur-unsur Kebudayaan dalam Potroses Kreatif. Yogyakarta: Pustaka Pelajar.

Rifai, A., Mustikawati, A., Kurniawati, D., Hariyanto, D., Misriani, \& Herawati, Y. 2018. Serpihan Cerita Rakyat Kalimantan Timur. Samarinda: Kantor Bahasa Provinsi Kalimantan Timur.

Sukojo, B. M. 2012. Toponimi (Arti dan Peran). Surabaya: ITS Press. 